\title{
Kernos
}

Revue internationale et pluridisciplinaire de religion grecque antique

23 | 2010

Varia

\section{Cults of Female Deities at Dion}

\section{Semeli Pingiatoglou}

\section{OpenEdition \\ Journals}

\section{Electronic version}

URL: http://journals.openedition.org/kernos/1578

DOI: $10.4000 /$ kernos. 1578

ISSN: 2034-7871

\section{Publisher}

Centre international d'étude de la religion grecque antique

\section{Printed version}

Date of publication: 1 January 2010

Number of pages: 179-192

ISSN: 0776-3824

Electronic reference

Semeli Pingiatoglou, «Cults of Female Deities at Dion », Kernos [Online], 23 | 2010, Online since 10 October 2013, connection on 02 May 2019. URL : http://journals.openedition.org/kernos/1578 ; DOI : 10.4000/kernos. 1578 


\title{
Cults of Female Deities at Dion*
}

\begin{abstract}
In this contribution, the female deities worshipped at Dion since its establishment as a city through to the Roman conquest are presented and the origin of the cult of these deities is investigated. The worship of the Muses, the only worship attested in ancient texts, was related to the worship of Olympian Zeus and supported by the Macedonian King Archelaos around the end of the 5th century B.C. as a means of expediency and propaganda. Demeter was an important female deity, whose cult was brought to light by the oldest archaeological evidence. Her sanctuary also hosted other minor female deities of fertility. The cult of these deities, in contrast to the cult of the Muses, was based on the worshippers' urge to communicate with those of the gods with whom a more intimate relationship was assumed and who could ensure their existence and welfare. Moreover, the worship of the Egyptian goddess Isis, introduced to Dion in the 2nd c. B.C., gradually overshadowed the worship of older deities, since Isis combined several of their qualities. As a consequence, her sanctuary became the most thriving shrine during the Roman period.
\end{abstract}

Résumé : Dans cette étude, on présentera les divinités féminines honorées à Dion depuis les origines jusqu'à la conquête romaine et on enquêtera sur l'origine de leur culte. Le culte des Muses, seul attesté dans les textes anciens, était lié à celui de Zeus Olympien et encouragé par le roi macédonien Archelaos vers la fin du ve siècle avant notre ère en tant que moyen de propagande. Déméter était une divinité féminine importante, dont le culte a été mis au jour par les témoignages archéologiques les plus anciens. Son sanctuaire accueillait également d'autres divinités féminines de la fertilité de moindre importance. Le culte de ces divinités, par opposition au culte des Muses, était fondé sur le désir du fidèle de communiquer avec les dieux avec lesquels une relation plus intime était supposée et qui pouvaient assurer leur existence et leur bien-être. De plus, le culte de la déesse égyptienne Isis, introduit à Dion au cours du $\mathrm{II}^{\mathrm{e}}$ siècle avant notre ère, a peu à peu éclipsé le culte de divinités plus anciennes, puisqu'Isis combinait plusieurs de leurs prérogatives. En conséquence, son sanctuaire est devenu le plus florissant durant la période romaine.

\footnotetext{
* Abbreviations:

AErgoMak

PANDERMALIS (1977)

PANDERMALIS (1997)

PANDERMALIS (1999)

Pingiatoglou (1991)

PingIATOGLOU

(forthcoming)

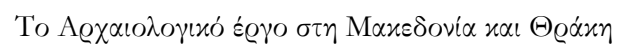

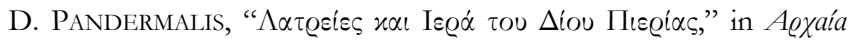

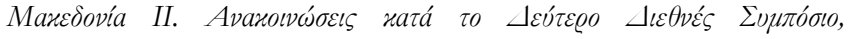

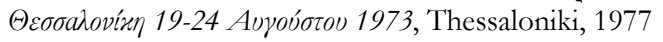

D. Pandermalis, Dion. The Archaeological Site and the Museum, Athens, 1997

D. Pandermalis, Aiov. H a

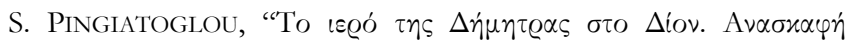
1991," AErgoMak 5 (1991), p. 145-156.

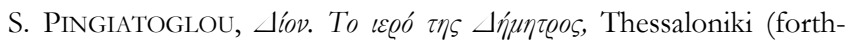
coming)
} 
The long uninterrupted excavation carried out by the staff of the Aristotle University of Thessaloniki has by now revealed precious information about the city and the religious life of ancient Dion. ${ }^{1}$ Since only the cult of Olympian Zeus and the Muses became known from written sources, the excavation has vastly enriched our knowledge about the religious practice of the inhabitants of Dion.

My contribution is essentially a presentation of all the evidence accumulated over the years about the cult of female deities until the foundation of the Roman colony, that is, a little after 30 B.C. My aim is to cast some light on the place that these deities had in the religious ideology of the Macedonians.

\section{The Muses}

What we gather from the ancient writers is that at the end of the 5 th century B.C. King Archelaos established the "Olympia," a festival which lasted nine days, each day dedicated to a Muse, and including games in honour of Zeus and the Muses. ${ }^{2}$

However, it should be borne in mind that the Muses at Dion were not related only to Zeus. There is a notable mention of them in relation to Dionysus on an inscription dating to the period of the last Macedonian King. On the pedestal of an honorary statue of Perseus (179-168 B.C.) it is mentioned that the "Mousaistai," i.e. the worshippers of the Muses and Dionysus who formed a group together, offered the statue of the King to the Muses and to Dionysus to honour his virtue, his benevolence towards their "Koinon" and his piety. ${ }^{3}$ The original position of this statue is not known. Also unknown is the original position of the statue of a Muse of the Late Hellenistic period, the two parts of which were found separately and were subsequently put together. ${ }^{4}$

\footnotetext{
${ }^{1}$ On an overview of the excavation: Pandermalis (1997); Pandermalis (1999); PanderMALIS et al., www.ancientdion.org.

2 Diod., XVII, 16; Dion Chrys., II, 2; Scholia Ulp. ad Demosth., 19, 192. The ancient literature in W. BAEge, De Macedonum sacris, Halle, 1913, p. 10-12. On the festival Olympia, see M. MARI, "Le olimpie macedoni di Dion tra Archelao e l'età romana," RFIC 126 (1998), p. 137-169; M. MARI, Al di là dell'Olimpo. Macedoni e grandi santuari della Grecia dall'età arcaica al primo ellenismo, Atene, 2002

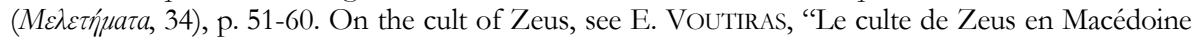
avant la conquête romaine," in M. Guimier-Sorbets, M.B. Hatzopoulos, Y. Morizot (eds.), Rois, cités, nécropoles. Institutions, rites et monuments en Macédoine. Actes des colloques de Nanterre (Décembre 2002) et d'Athènes (Janvier 2004), Athènes, 2006, p. 333-345, esp. 335-338.

3 This base was at a later time recarved into the shape of a Doric column capital and later used as building material for the construction of a private Roman house, where it was found. See

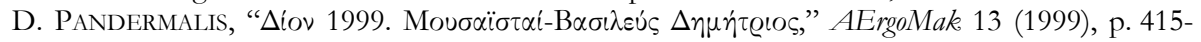
417; SEG 49 (1999), no. 697; M.B. Hatzopoulos, BE 2001, no. 273; D. Pandermalis, "New Discoveries in Dion," in M. Stamatopoulou, M. Yeroulanou (eds.), Excavating Classical Culture. Recent Archaeological Discoveries in Greece, Oxford, 2002, p. 101-103.

${ }^{4}$ While the lower part was found on the main street of the ancient city, the upper part was found in a wall of a building inside the temenos of Demeter, see PINGIATOGLOU (forthcoming).
} 
Perhaps it was originally placed in the temenos of the Muses, but the possibility that it might have decorated a private residence cannot be excluded.

The sanctuary of the Muses at Dion has not been found; there is, however, suggestive and reliable evidence that it might have been situated near the sanctuaries of Olympian Zeus ${ }^{5}$ and Dionysus, ${ }^{6}$ which were close to one another, in an area rich in water supply. In either case, it is possible that the Muses might have been worshipped along with Zeus or Dionysus in the same sanctuary. I would like to come now to the issue of the goddesses for who the only source of information are the finds of the excavations.

\section{Demeter}

The oldest and most plentiful surviving archaeological evidence revolves around the cult of the goddess Demeter. The cult of that deity had been long attested, in particular from the beginning of the 5th century B.C. until the later period of antiquity-about the end of the 4th century A.D. The temenos, the oldest ever sanctuary of the goddess which has been excavated in Macedonia, exhibits rich finds concerning the era under consideration, viz. the Classical and the Hellenistic periods. ${ }^{7}$

Temples belonging to different periods are located side by side, except for the two earlier ones which are located to the west of the two large Hellenistic temples. Starting from the Hellenistic era, we notice a gradual expansion of the temenos to the north. On the architectural plan (Fig. 1) the buildings are numbered for convenience. Two Late Archaic or Early Classical temples of the "megaron" type have been discovered $(1,2)$, replaced by two Hellenistic temples $(3,4)$. A few more Hellenistic buildings were also discovered, two small one-room naiskoi $(8,10)$, a building with a well $(7)$ and a stoa (12). To the north of the northern Hellenistic temple (4) seven more buildings from the Imperial period were found.

Let us next take a look into the very important worship buildings of the temenos.

\footnotetext{
${ }^{5}$ Cf. PAndermalis (1999), p. 44-59.

${ }^{6}$ Concerning the location of the sanctuary of Dionysos, see PANDERMalis (1977), p. 331 333.

${ }^{7}$ For an overview of the sanctuary of Demeter see PANDERMalis (1999), p. 60-73. On its excavation see Pingiatoglou, AErgoMak 4 (1990), p. 205-215; 5 (1991), p. 145-156; 6 (1992), p. 223-233; 10 (1996), p. 225-232; 15 (2001), p. 355-362; 17 (2003), p. 425-434; S. PINGIA-

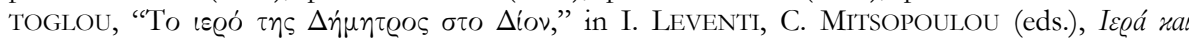

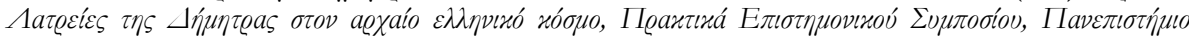

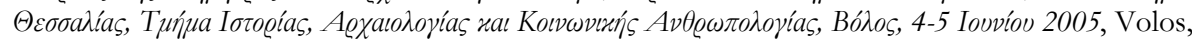
2010, p. 201-224; Pingiatoglou (forthcoming).
} 

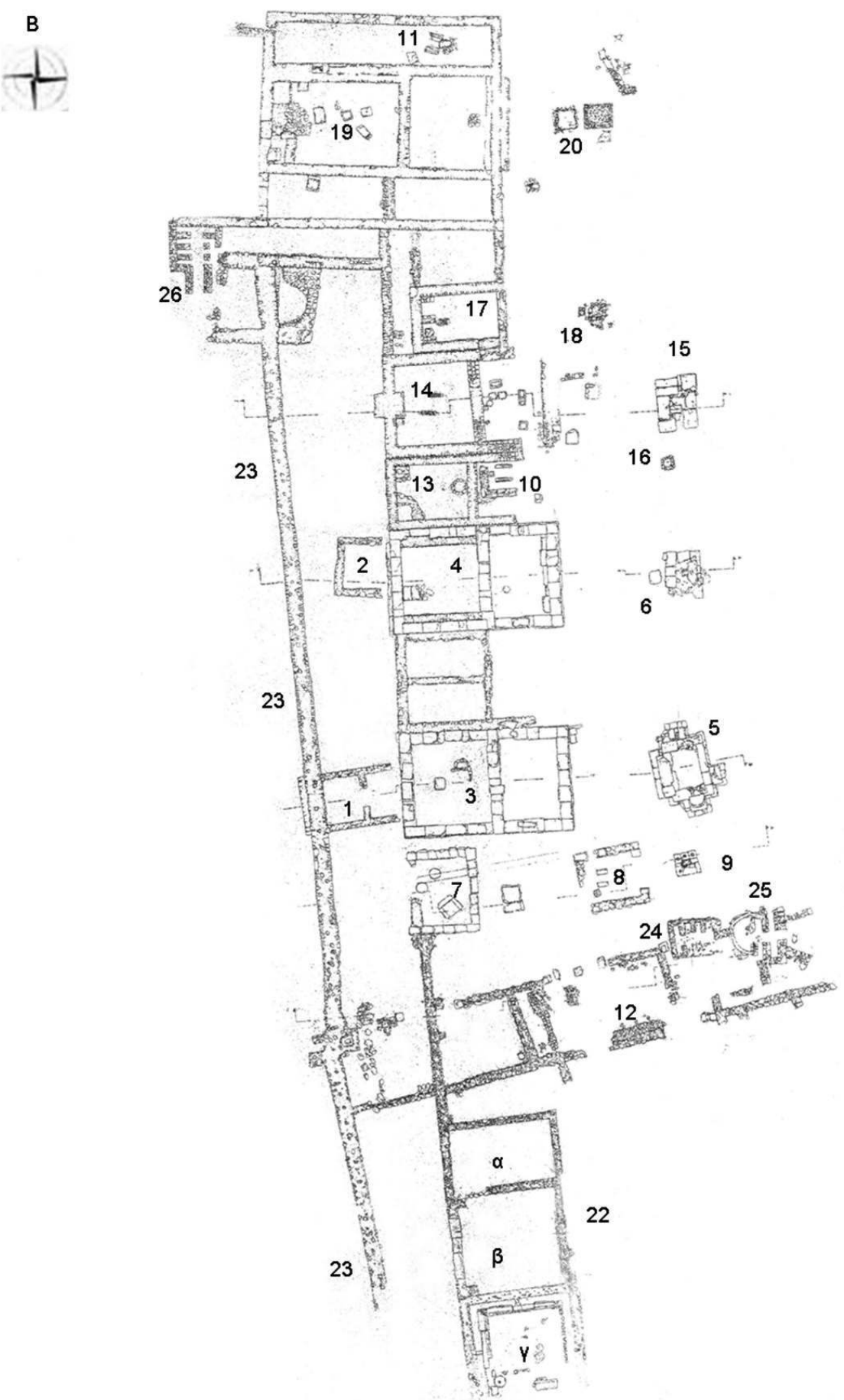

Fig. 1 
Two small temples of the "megaron" type $(1,2)$ were the earliest sites with the oldest signs of worship in their interior and the surrounding area. The structure of the walls and the finds point to the Late Archaic or Early Classical period. In the cella of the northern megaron (2) the finds include terracotta statuettes, vases, a glass alabastron, jewellery and others. In the cella of the southern megaron (1), amongst the finds are fragments of red-figure vases dating from the first half of the 4th century B.C., many black-glazed lamps of the typology of the 5th century B.C., which survived until the first decades of the 4th century B.C.; ${ }^{8}$ terracotta statuettes, vases, a kernos in the form of a ring, and miniature hydrias. ${ }^{9}$ Put together all this evidence provides support to the hypothesis that in the middle of the 4th century B.C., perhaps even slightly later, the temples were replaced by two larger ones, the north and the south Hellenistic temples $(3,4)$. Both those temples had two Doric columns in antis in the facade, with their cella and pronaos facing east. Their foundations, the toichobates plus a series of orthostates, built of ashlar stone blocks, are preserved in good condition. Statues of "peplophoroi" and other sculptures were found in their interior. ${ }^{10}$

The remains of an "eschara" with signs of burning, bones and offerings were discovered below the level of the pronaos of the north Hellenistic temple (4). The offerings and the coins show that this "eschara" was in use during the Classical period. ${ }^{11}$

Of special interest, as far as worship practices are concerned, is the so-called "building with the wells" (7). The entrance is on its eastern side. At its interior south-east corner, at the floor level, the almost square rim of a well (side length $90 \mathrm{~cm}$ ) was found. Underneath the floor of the same area, there was a rich stratum showing clear signs of destruction, including traces of fire, bones, and numerous offerings, such as statuettes and miniature vases, from the Classical period, the 5 th and the 4th century B.C. ${ }^{12}$ The rims of two circular wells (of $72 \mathrm{~cm}$ and $80 \mathrm{~cm}$ in diameter) with clay wall covering suggest that the floor of the Early Classical phase of the shrine was $55 \mathrm{~cm}$ deeper than the level of the Hellenistic phase. The destruction layer with many offerings indicates that this place was really devoted to worship. The construction of an enclosure as better means of demarcation and the replacement of the simple wells of the Classical period by a larger one with a stone rim corroborate its sacred character. The wells for drawing water, perhaps local imitations of the "Kallichoron" well, the

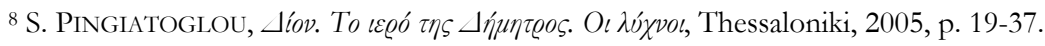

${ }^{9}$ For the finds of both Classical temples, see Pingiatoglou (1991), p. 145-156.

10 Pandermalis (1999), p. 70-73. Pingiatoglou (forthcoming).

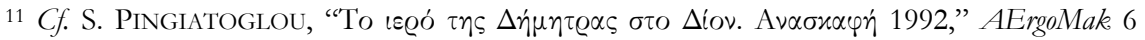
(1992), p. 226.

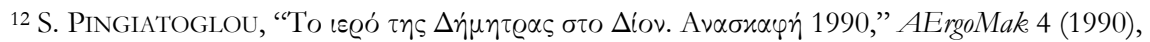
p. 205-215.
} 
sacred source of Eleusis, were the places where the worshippers would pray, and depose their gifts to the goddess.

To the east of the building with the wells an almost square one-room naiskos with a large opening at its eastern side was brought to light (8), its interior revealing two vertical supports of a horizontal table of offerings standing upright in their original position. The coins and the clay artifacts help us date this "oikos" and the altar in front of it to the 3rd century B.C. Parts of a similar oikos (10) with a table for offerings survived under the floor of the pronaos of one of the temples of the Imperial era. In front of each temple stood an altar built of stones and/or bricks. The southern boundary of the sanctuary was a stoa (12) with wooden supports ${ }^{13}$ facing the temples.

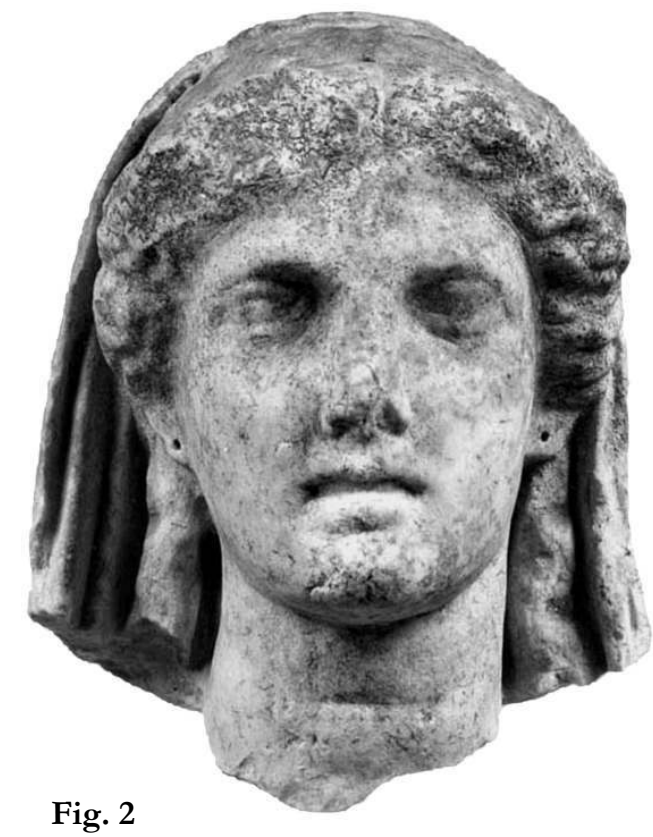

During the first year of the excavation - 1973 - when a female marble head covered with mantle (Fig. 2) was found in the south Hellenistic temple, the hypothesis was made that the figure depicted Demeter and the temple was devoted to her. ${ }^{14}$ This early hypothesis about the identity of the goddess worshipped there was confirmed later on, when a fragmentary skyphos from the 4th century B.C. with Demeter's name on it was found..$^{15}$ It was incised in a votive inscription above the base of the cup.

The reconstruction of the cult of Demeter at Dion, because of lack of written sources, is based exclusively on archaeological finds, on comparisons with artifacts from other shrines, and on information from written sources about other sanctuaries. ${ }^{16}$

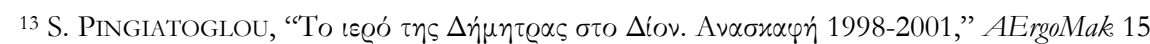
(2001), p. 355-362, esp. 355-358.

14 Pandermalis (1977), p. 335.

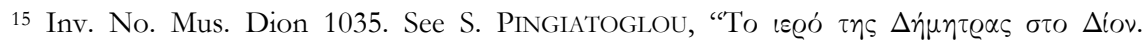

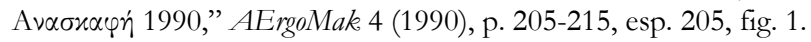

${ }^{16}$ For the cult of Demeter, see M. NiLSsON, A History of Greek Religion, Oxford, 1949², p. 108109; W. BurKerT, Griechische Religion der archaischen und klassischen Epoche, Stuttgart, 1977, p. 247251; E. SimON, Die Götter der Griechen, München, 19984, p. 80-98. For extensive bibliography see: 
Apart from animal sacrifices, the worshippers offered the goddesses a variety of objects. The most common votive offerings at Demeter's sanctuary of Dion were terracotta statuettes, especially standing female figures, busts and hydriaphoroi. A necessary requirement for the worship was the ritual purification in water, as inferred from the numerous hydria-vases and hydrias carrying statuettes. ${ }^{17}$ Such rituals were common in almost all of Demeter's shrines, and hydrias and hydriaphoroi are among the most characteristic finds in them. ${ }^{18}$

From the Hellenistic period onwards small marble statues of gods and perhaps of priestesses and children were typical offerings. Vases, jewellery and lamps ${ }^{19}$, utilitarian or votive, or both, abounded in the sanctuary.

No precious offerings survived, however. But there are still a few such offerings standing out for their high quality and the material out of which they were made, and which evidence the former wealth of the sanctuary. The most impressive find is the Mycenean seal stone dating to the 15th century B.C., schematically depicting a lion in front of a tree. ${ }^{20}$ Another unique find, namely a glass bowl ("phiale") from the 4th century B.C., ${ }^{21}$ was found next to the seal stone. Since all these were precious offerings, it is reasonable to assume that they must have been kept together inside the south Late Archaic megaron.

I believe that the most characteristic element in this sanctuary was that in all the phases of its life there were two separate temples, which, however, were

R. Di Donato, Hiera. Prolegomena ad uno studio storico anthropologico della religione greca: periodo arcaico e classico, Pisa, 2001.

17 Pingiatoglou, l.c. (n. 15), p. 205-215, esp. 208-209, fig. 6a, 8 a.

18 Among the duties of the priestesses of Demeter was to bring pure water from the holy fountain, as Callimachos wrote in his Hymn to Apollo, 2, 110-112. Cf. for example an inscription

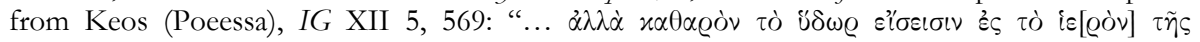
$\Delta \eta \dot{\mu \eta} \tau \varrho o[s] . "$

19 Pingiatoglou, o.c. (n. 8), passim.

20 Mus. Dion, Inv. nr. 608. See PANDERMALIS (1997), p. 17 (fig.). Sakellarakis considers two alternative possibilities for similar finds: 1) The seal stone was a relic of a family that was inherited down, 2) it came to the dedicator by chance after the sack of a Mycenean tomb. Even though the first possibility is more attractive, as Sakellarakis himself discusses, it cannot be proved. See J.A. SAKELLARAKIS, "Kretisch-mykenische Siegel in griechischen Heiligtümern," in Neue Forschungen in griechischen Heiligtümern. Internationales Symposion in Olympia vom 10. bis 12. Oktober 1974 anlässlich der Hundertjabrfeier der Abteilung Athen und der deutschen Ausgrabungen in Olympia, Tübingen, 1976, p. 283-308, esp. 305.

21 It belongs to a group of rare glass vases, having Persian metal originals and dating from the beginning of the 5 th century B.C. to the end of the 4th century B.C. The phiale and the other finds discovered with it do not lead us to a more precise dating, except from a bronze coin of the 2nd half of the 4th century B.C., which constitutes a chronological indication for the stratum. For

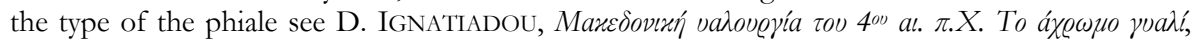
Thessaloniki, 2004 (diss.), p. 137-139. On another votive glass bowl, see Chr. SCHAUER, "Eine Glasschale für Artemis: Neue Evidenz zur Verbreitung von klassischen Luxusglas in Griechen-

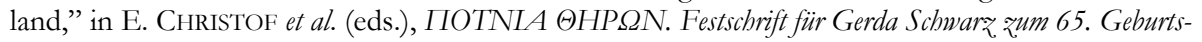
tag, Wien, 2007, p. 371-376. 
very similar. It is noteworthy that the wells of the earlier stage were also two. ${ }^{22}$ Moreover, the fact that the buildings come in pairs $(1-2,3-4,5-6,8-9)$ reflects a parallel worship of two deities, i.e. the two temples belonged to Demeter and a younger attendant deity. No inscription indicating the worship of Kore was found in Dion. Nevertheless, her presence in the sanctuary is suggested by a unique terracotta statuette of a running female figure carrying a kalathos with a snake creeping towards it. It is because of the specific iconography that I take the female figure to represent Kore. ${ }^{23}$ The archaeological finds, statues, statuettes and inscriptions, indicate the presence of Aphrodite too and support the idea that she was also worshipped in this particular temenos. ${ }^{24}$ However, whenever Aphrodite is related to Demeter, she usually bears features, akin to those of Kore. I conjecture that in Dion the attendant deity of Demeter was Aphrodite. ${ }^{25}$

22 There are no exact parallels for sanctuaries of Demeter with two temples. According to Pausanias therefore in the City Eleusinion in Athens there were two temples, one of Demeter and Kore and another of Triptolemos (Paus., I, 14, 1). See M.M. Miles, The City Eleusinion (The Athenian Agora, vol. 31), Princeton, New Jersey, 1998, p. 44, 48-52. During the Roman period there were three temples in the sanctuary of Demeter at Acrocorinth, see R. STROUD, N. BookIDIS, Corinth XVIII.3. The Sanctuary of Demeter and Kore. Topography and Architecture, Princeton, New Jersey, 1997, p. 337-371, esp. 362-371. There are three contemporary altars in the sanctuary of Demeter Malophoros in Selinus, see R. Koldewey, O. PuchsteIn, Die griechischen Tempel in Unteritalien und Sizilien, Berlin, 1899, p. 82-90, Taf. 11; V. Hinz, Der Kult von Demeter und Kore auf Sizilien und in der Magna Graecia," Wiesbaden, 1998 (Palilia, 4), p. 145-152, fig. 35 (with earlier references).

${ }^{23}$ We see in it the Orphic version of the myth, according to which Persephone was raped by Zeus transformed into a snake while she was picking flowers. From this union Zagreus-Dionysos was born, see Pingiatoglou (1991), p. 147-148.

${ }^{24}$ We can conclude the relationship between the Eleusinian deities and Aphrodite from the neighbourhood of some of their sanctuaries, for example the sanctuaries of Aphrodite Pandemos, Ge Kourotrophos and Demeter Chloe under the Propylaia of the Acropolis at Athens (Paus., I, 22, 1-3). Cf. the neighbourhood of the sanctuaries of Aphrodite Ourania and Eileithyia in the sanctuary of Zeus in Olympia (Paus., VI, 20, 6), close by Gaion (Paus., V, 14, 10). There are also representations of the Eleusinian deities and Aphrodite in the same monument: for example on two votive reliefs, one from the sanctuary of Aphrodite at Daphni and the other from the Agora of Cyrene, see L. BESCHI, s.v. "Demeter," LIMC IV (1988), p. 881, no. 439, 440. On Cyrene see also L. BACCHIELLI, Parole d'oltremare e altri scritti di archeologia, Urbino, 2002, p. 119, 122, pl. 15-3. Delivorrias has treated the relationship between the Eleusinian deities and Aphrodite in his article: A. DeLIVORRIAS, "Doppeldeutigkeiten und Mißdeutungen," in H. Froning, T. Hoelscher, H. Mielsch (eds.), KOTINOE. Festscbrift für E. Simon, Mainz, 1992, p. 184-185. See also A. Delivorrias, s.v. “Aphrodite," LIMC II (1984) p. 130, no. 1367-1371 (vases with Aphrodite in Eleusinian cycle). For

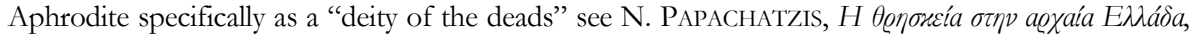
Athina, 1987, p. 136-140. Cf. C. Sourvinou-Inwood, "Persephone and Aphrodite at Locri. A Model for Personality Definitions in Greek Religion," JHS 98 (1978), p. 101-121. A statuette of Aphrodite was found also in the sanctuary of Demeter in Rhodos: E. ZERVOUDAKI, "Vorläufiger Bericht über die Terrakotten aus dem Demeter-Heiligtum der Stadt Rhodos," in Archaeology in the Dodecanese. Symposium Copenhagen April 7t to 9th, 1986, Copenhagen, 1988, p. 129-130, 134, fig. 5.

25 The kind and the number of the archaeological finds related with Aphrodite do not allow us to suppose that Aphrodite was only a visitor deity. On the visitor deities see B. ALroth, "Visiting Gods-Who and Why," in T. Linders, G. NordQuist (eds.), Gifts to the Gods. Proceedings 
In ancient Greek sanctuaries the coexistence of deities with similar characteristics was a common phenomenon. Votive inscriptions and other offerings indicate that at this temenos Baubo, ${ }^{26}$ Kourotrophos, ${ }^{27}$ Cybele, ${ }^{28}$ Artemis ${ }^{29}$ and Eileithyia ${ }^{30}$ were also worshipped.

\section{Praxidika}

A random find in the summer of 2007 (a base with a votive inscription) added to the list of goddesses a minor deity, Praxidika. The fact that Praxidika was worshipped in Dion was not known before. From the written sources we know that she was the goddess who bestowed justice, a goddess of oaths and revenge. Because Praxidika sometimes appears as an epithet of Persephone, we

of the Uppsala Symposium 1985, Uppsala, 1987 (Boreas, Uppsala Studies in Ancient Mediterranean and Near Eastern Civilizations, 15), p. 9-19.

${ }^{26}$ A votive inscription to Baubo, a demonic figure of the Eleusinian cycle according to the orphic version of the story of Demeter, highly likely originated in this sanctuary. If this is true, it indicates that Demeter was probably worshipped at this temenos as an Eleusis deity ("Eleusinia"). On the votive inscription see PANDERMALIS (1977), p. 335-336, fig. 4. It should be noted, however, that this is the first known reference of a priestess of Baubo. On Baubo see T. KARAGHiORGa-STATHAKOPOULOU, s.v. "Baubo," LIMC III (1986), p. 87-90.

27 The word Kov@or@ó $\varphi[0]$ on the base of an offering which was found in the temenos may be either the name of an "independent" goddess Kourotrophos, or it may be an epithet of Demeter. The finds, for example a small marble statuette of a standing boy and two terracotta statuettes, also of boys, point to the worship of a deity who protected childhood. See PINGIATOGLOU (forthcoming).

28 Also a terracotta statuette of Cybele was found. Pingiatoglou (1991), p. 147, fig. 9. Although this is an isolated example, perhaps it is not fortuitous. Demeter is a goddess related to Cybele, who was a mother-like deity identified with the Mother of Gods. There is evidence of her existence also in other sanctuaries dedicated to Demeter ( $c f$. for example the shrines of Halicarnassus [R.A. Higgins, Catalogue of the Terracottas in the Department of Greek and Roman Antiquities, British

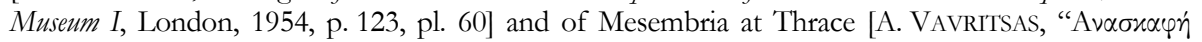

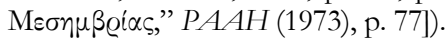

${ }^{29}$ One Late Archaic statuette of Artemis perhaps is not sufficient evidence for the co-worship of Artemis at the temenos. Pingiatoglou (1991), p. 147, fig. 8. About the dedication of statuettes of Artemis see also B. Alroth, Greek Gods and Figurines. Aspects of the Anthropomorphic Dedications, Uppsala, 1989 (Boreas, Uppsala Studies in Ancient Mediterranean and Near Eastern Civilizations, 18), p. 109113. However, a foot with "endromis" of a terracotta statuette (Mus. Dion, Inv. No. 799) might as well have been part of an Artemis statuette. Furthermore, a votive inscription to Apollo and Artemis

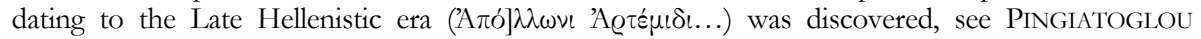
(forthcoming). Therefore, the co-worship of Artemis remains a viable hypothesis, since we have multiple indications to that effect. In any case, there are many parallels from elsewhere supporting the relation of Artemis and Demeter, see Pingiatoglou (2010), l.c. (n. 7), p. 211.

$30 \mathrm{~A}$ base with a fragmentary Hellenistic votive inscription for Eileithyia was found also in the sanctuary of Demeter at Dion, see Pingiatoglou (forthcoming). The nature of Eileithyia as a goddess of childbirth may explain the fact that she was worshipped together with fertility goddesses. However, we cannot exclude the possibility that the inscription was transported from the area of the nearby Isis sanctuary, where there is also evidence about the cult of Artemis Eileithyia, see infra (n. 37). 
conjecture that she too was worshipped in the area of the temenos of Demeter. ${ }^{31}$ Now, the great number of altars, pointing to a rich worship activity, suggests that multiple deities were worshiped in the temenos. ${ }^{32}$

\section{Hygeia}

Another female deity, Hygeia, appeared at Dion when the cult of her father, the god of health Asclepios, was established in the area near the oldest temenos of Demeter around the end of the 4th or the beginning of the 3rd century B.C. (Fig. 3). The cult of Asclepios became very important at Dion, especially during the Imperial era. ${ }^{33}$ As suggested by ancient Greek texts and by archaeological finds, there was a connection between the Eleusinian deities and Asclepios, and many shrines of Asclepios were often founded near the shrines of Demeter. $^{34}$

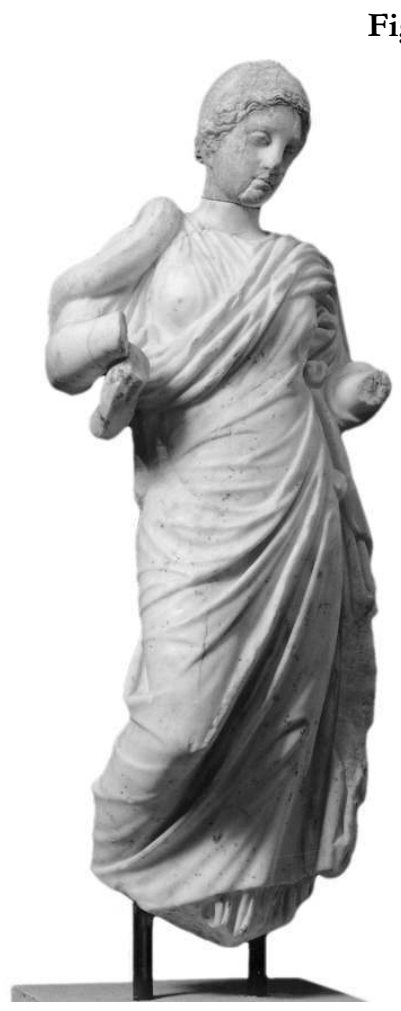

Fig. 3

31 The pedestal with the inscription will be published soon by this author in a volume in honour of D. Pandermalis.

32 In the temenos there are six altars built of stones or brick, cult tables and pits for liquid offers. The existence of many altars originating in different historic periods in a sanctuary may be due to only one cult over a long period, but in conjunction with other finds such as inscriptions or sculptures it may be one more piece of evidence for the parallel worship of two or more deities. Even closely related deities such as Demeter and Kore were sometimes worshipped on separate altars in the same temenos. This must be the case of the altars in the sanctuary of Demeter at Dion, since some of the altars are contemporaneous and belong to different contemporaneous temples. This is the case, for example, of the Eleusinian sanctuary as is inferred from various inscriptions, ancient texts and archaeological finds, see K. CLINTON, "Sacrifice at the Eleusinian Mysteries," in Early Greek Cult Practice, Stockholm, 1988, p. 71-72, n. 29, 30. Cf. the scene on a red-figure stamnos of Painter of Triptolemos (Louvre) with the two goddesses Demeter and Kore, each one of them behind her own altar, on either side of Plouton or Keleos, see K. SCHEFOLD, Frühgriechische Sagenbilder in der klassischen und bellenistischen Kunst III, München, 1981, p. 59, fig. 73.

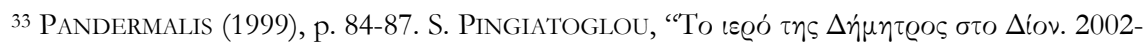
2003," AErgoMak 17 (2003), p. 429-432.

34 On the close links between Asclepios and Demeter, see Pingiatoglou, l.c. (n. 33), p. 430 432. See also Chr. BENEDUM, "Asklepios und Demeter. Zur Bedeutung weiblicher Gottheiten für den frühen Asklepioskult," JDAI 101 (1986), p. 140. For similarities between the cult of the Eleusinian goddesses and the cult of Asclepios, see R. GARLAND, Introducing New Gods. The Politics of Athenian Religion, London, 1992, p. 124. 


\section{Isis}

The cult of Isis was introduced during the Hellenistic period and her sanctuary thrived in the Imperial era. ${ }^{35}$ The earliest evidence is a votive inscription to Isis, Sarapis and Anubis on a votive relief from the 2 nd century B.C. found on the steps of the main temple in the sanctuary of Isis. This inscription suggests that the introduction of the Egyptian goddess and her circle was

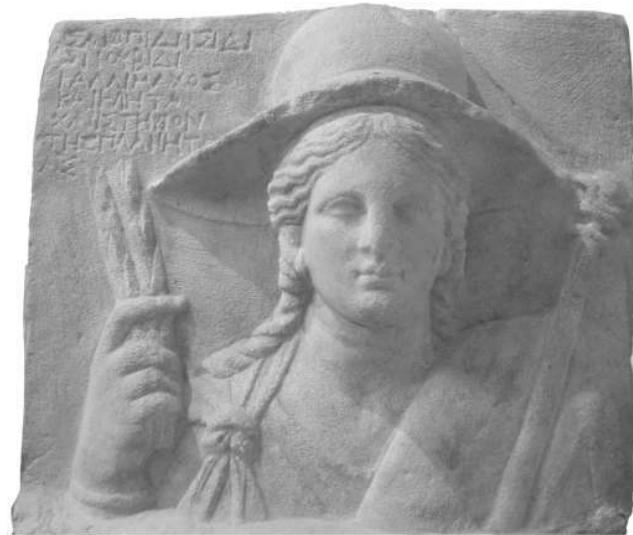

Fig. 4 completed during that time at the latest (Fig. 4). ${ }^{36}$ The goddess was worshipped as Lochia according to votive inscriptions dating from the 3 rd century A.D. found in the sanctuary. A votive inscription to Artemis Eileithyia dating from the 3rd century B.C. was found as well near the main temple of Isis. ${ }^{37}$ This raises the question of the possible pre-existence in the same place of a sanctuary of Artemis Eileithyia and Isis Lochia was just installed in it because of the same nature.

\section{Aphrodite and Athena}

A statue of Aphrodite from the Hellenistic period was reused on a new pedestal in the Imperial era as the cult statue of Aphrodite Hypolympidia in a small naiskos of the sanctuary of Isis (Fig. 5). This is evidence that Aphrodite continued to be worshipped during that period. ${ }^{38}$

A votive inscription to Athena was found on a fragment of a cylinder altar in the area of the shrine of Olympian Zeus mentioned above, just a few meters north of the Roman theatre. The inscription dates to the 2 nd century B.C. and

35 PANDERMALIS (1999), p. 88-115.

36 See D. Pandermalis, "Ein neues Heiligtum in Dion," AA (1982), p. 727-735, esp. 732.

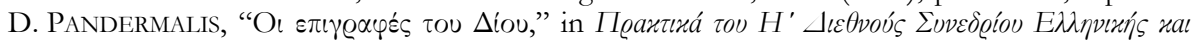

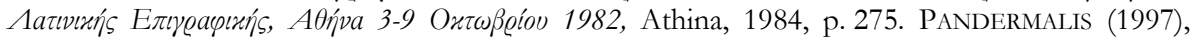
p. 22 (fig.).

${ }^{37}$ For the inscriptions, see PANDERMaLis (1984), l.c. (n. 36), p. 273-275. See also S. PINGIATOGLOU, Eileithyia, Würzburg, 1981, p. 112-113. Cf. M. GIUMAN, "Metamorfosi di una dea: Da Artemide ad Iside in un santuario di Dion," Ostraka 8 (1999), p. 427-446. On the sanctuary of Isis, see PANDERMALIS (1999), p. 88-117. On the diffusion of the cult of Isis in general: P. PAKKANEN, Interpreting Early Hellenistic Religion. A Study based on the Mystery Cult of Demeter and the Cult of Isis, Helsinki, 1996.

38 PANDERMalis (1999), p. 104-109. 
is evidence of either a co-worship of the goddess in the shrine of Zeus or her worship in a separate, though neighbouring, shrine. Another fact that points to the importance of Athena's worship in Dion is the depiction of her figure on the back side of coins minted in Dion dating to the Imperial period. ${ }^{39}$

\section{Worship of these deities}

Around the end of the 5th century B.C., in an effort to reform his kingdom and to restructure it in a way similar to the states of the rest of Greece, King Archelaos of Macedonia decided to reconstruct the cult of Olympian Zeus following the example of panhellenic sanctuaries, e.g. those in Olympia or Dodona, so that his kingdom got to own a similar strong religious center. For this reason he founded "Olympia," a nine day festival in honour of Zeus and the Muses. ${ }^{40}$ With this festival Archelaos had probably two things in mind: On the one hand to underline his deep concern about all that the Muses represented in the ancient Greek world, i.e. intellectual life and culture, and, on the other, to remind everyone of the old Hesiodic myth which established a special link between the Olympian Muses and the area of Pieria, in other words to remind people of the myth that in Pieria Zeus gave life to the Muses after his union with Mnemosyne. ${ }^{41}$ We would therefore assume that with

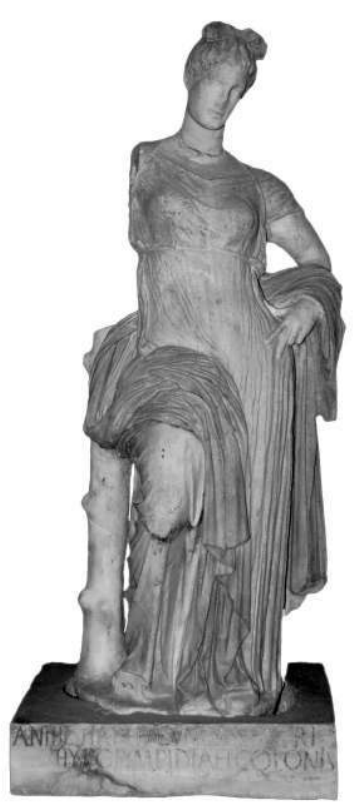

Fig. 5 regard to the Muses the promotion of their worship was part of the propaganda launched by King Archelaos. Another indication of the importance of the worship of the Muses for the royal family is an epigram transmitted down by Plutarch's Moralia. ${ }^{42}$ It is about a dedication of Eurydice to the Muses. Eurydice was the daughter of Sirras and grandmother of Alexander the Great.

In general, in the ancient Greek world, wherever there was an organized settlement with agriculture as its economic base, there was also a sanctuary of

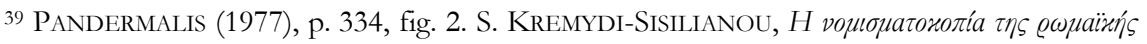

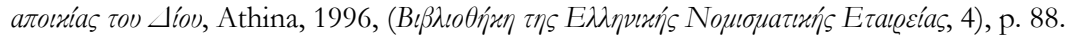

${ }^{40}$ Cf. supra (n. 2).

${ }^{41}$ Hes., Theog., 51-54.

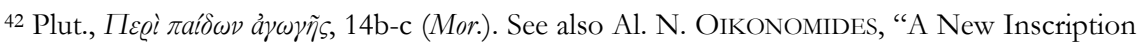
from Vergina and Eurydice the Mother of Philip II," $A n c W 7$ (1983), p. 64. Chr. SAatsoglouPAliadeli, "Queen Appearances at Vergina-Aegae. Old and New Epigraphic and Literary Evidence," $A A$ (2000), p. 401-403. 
Demeter, goddess of agriculture, as this goddess was the one to protect the crops and guarantee the survival of the settlement.

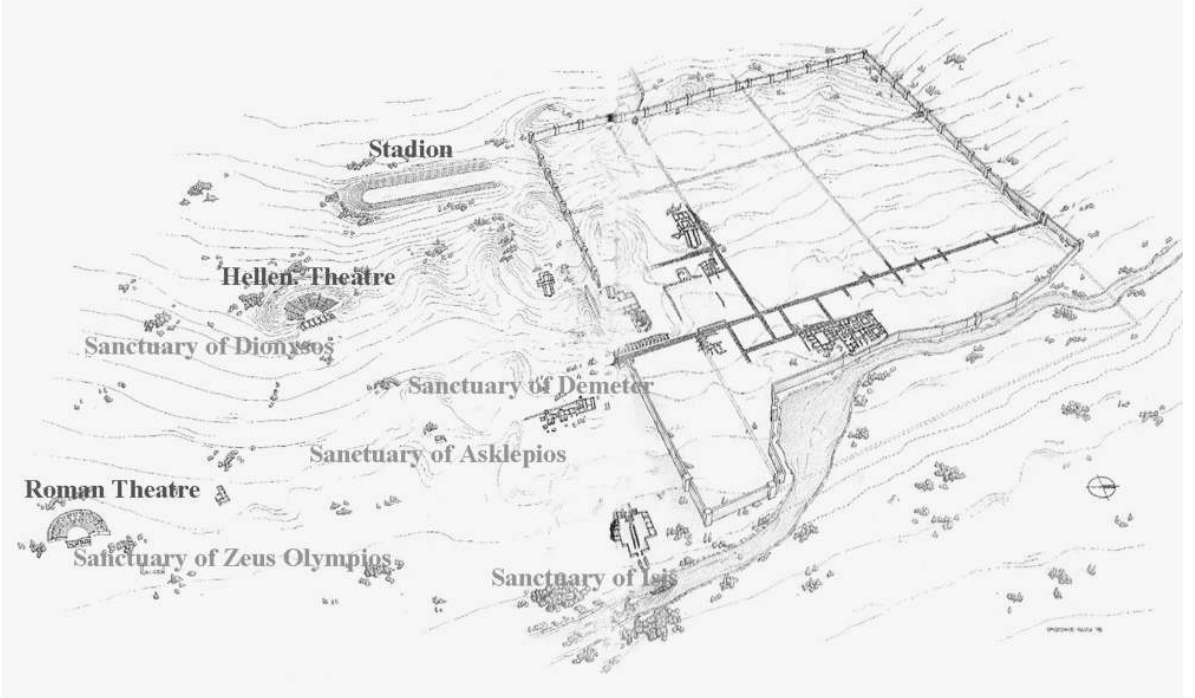

Fig. 6

The fact that this temenos of Demeter in Dion dates from about the beginning of the 5 th century B.C. leads us to assume that there was already a small Macedonian settlement next to the shrine of Olympian Zeus, perhaps following the unification of smaller settlements, at the beginning of this century at the latest. ${ }^{43}$ We note that the oldest written reference of Dion is found in Thucydides (424 B.C.). ${ }^{44}$ In other words, the archaeological sources date from at least half a century earlier. The choice of the location for the establishment of a temenos dedicated to an Earth goddess cannot be accidental. The inspiration for the origin of the worship must have been the lush landscape and the numerous water springs, which continue to flood the shrine to this day, as well as the fertile land all around.

Zeus and Demeter were the first gods who were worshipped in Dion. Their sanctuaries gradually attracted other gods as well: Dionysus and Athena were established near Zeus and the Muses, Aphrodite and lesser chthonian fertility goddesses, such as Baubo, Kourotrophos, Eileithyia, perhaps Praxidika too, were established next to Demeter. Later on, further east and near the river Baphyras, where Artemis Eileithyia was most likely worshipped, the cult of Isis under the names of Lochia and Tyche was founded. The sanctuaries of all those gods and goddesses were gathered around the two oldest sanctuaries that

43 S. Pingiatoglou, "Das religiöse Leben in Dion von den Anfängen bis in augusteische Zeit," in Festkolloqium für H. Froning 15-16. Mai 2009, Marburg (forthcoming).

44 Thuc., IV, 78, 6. 
existed outside the southern fortification wall of the city. But although situated extra muros (Fig. 6), they constituted a significant separate unit. Archelaos' intention for the sanctuary of Olympian Zeus to become a pan-Macedonian religious center was thus realized.

Semeli Pingiatoglou

University of Thessaloniki

Department of Archaeology

GR - 54124 THESSALONIKI

E-mail:semeli@bist.auth.gr

\section{List of figures}

Fig. 1 Architectural plan of the sanctuary of Demeter (Archive of the excavation of the Aristotle University of Thessaloniki).

Fig. 2 Head of a statue of Demeter from her sanctuary (Archive of the excavation of the Aristotle University of Thessaloniki).

Fig. 3 Statue of Hygieia from the sanctuary of Asclepios (Archive of the excavation of the Aristotle University of Thessaloniki).

Fig. 4 Votive relief from the sanctuary of Isis (Archive of the excavation of the Aristotle University of Thessaloniki).

Fig. 5 Statue of Aphrodite Hypolympidia from the sanctuary of Isis (Archive of the excavation of the Aristotle University of Thessaloniki).

Fig. 6 Plan of Dion. The sanctuaries and the city (Archive of the excavation of the Aristotle University of Thessaloniki/Drawing of Orkopoulos - Palli 1995) [PANDERMALIS (1997), p. 14-15]. 